\title{
Interactions of Legislative Environment, Ownership Structures and Control Rights: A Review of Literature
}

\author{
Meltem Gurunlu \\ Department of Accounting and Auditing, Maltepe University \\ PO box 34857, Istanbul, Turkey
}

Tel: 90-216-626-10-50Ｅ-mail: meltemg@maltepe.edu.tr

This paper has been accepted to be presented at the 9th international conference of JEPA (Japan Economic Policy Association which will be held by Waseda University in Tokyo, 27-28 November 2010.

\begin{abstract}
The legislative environment prevailing in an economy can be an important determinant of how the firms are governed and the extent to which minority shareholders and other stakeholders are protected. The results of empirical literature on legislative environment as an external corporate governance mechanism indicate that legal and regulatory mechanisms are fundamental determinants in the evolution of corporate governance structures (LaPorta, Lopez-de-Silanes, Shleifer and Vishny (1997, 1998, 1999, 2000 and 2002). In an ideal corporate governance model, one share is equal to one vote which means that cash flow right (ownership right) is equal to the control right (voting right). In reality, trade offs exist between ownership and control rights in every system no matter what the country's corporate governance system is classified as: - an outsider (dispersed ownership structure) or insider (concentrated ownership structure) -.

This paper aims to investigate the comprehensive literature on investors protection topic and taxonomy of different corporate governance systems of countries from various legal origins. In this context, this paper analyzes different mechanisms to concentrate or diffuse control rights with reference to Turkish Commercial Code and Capital Market Laws.
\end{abstract}

Keywords: Corporate Governance, Ownership, Legislative environment, Control and cash flow rights

\section{JEL Classification: G3}

\section{Introduction}

Legal Approach to corporate governance contends that the legislative environment in an economy is an important determinant of the way the firms are governed and is a sign of how effectively the minority shareholders and other stakeholders are protected. The comprehensive literature provided by LaPorta, Lopez-de-Silanes, Shleifer and Vishny (1997, 1998, 1999, 2000 and 2002) asserts that legal protection is a critical factor which may reduce the expropriation by the agents (owner-manager) and documents significant differences in the levels of investor protection, ownership concentration, dividend policies, creditor rights and enforcement abilities among various legal systems. Their findings can be summarized as follows:

- Common law countries provide better protection to minority shareholders and have firms which are valued more,

- Enforcement is best among Scandinavian legal origin countries,

- Creditor rights are best protected among common law countries,

- The level of ownership concentration is negatively related to the degree of investor protection.

- Ownership concentration is highest among French-civil-law countries

The above mentioned results indicate that legal mechanisms determine the differences between the evolution of corporate governance structures across countries. According to the classification by La Porta, Lopez-De-Silanes, Shleifer and Vishny (1998, pp:117-120), there are four legal origins:

- Common law (USA, UK, Australia, Canada, India, etc)

- French Civil law (France, Turkey, Italy, Spain, Portugal, Argentina, Greece, Brazil, Belgium, Egypt, Chile, etc)

- German civil law ( Germany, Austria, Japan, Switzerland, South Korea, Taiwan, etc)

- Scandinavian civil law (Denmark, Finland, Norway, Sweden 


\section{The Effects of Legal Systems on Corporate Governance Structures}

In Anglo-Saxon countries such as United States and the United Kingdom, common law system reigns and the legisative system empowers investors rights. In these countries, judges make common law by resolving specific cases. The previous judicial decisions are then incorporated into the written law and form the solution basis for the disputes in the future. Another important concept for common law countries is the fiduciary duty which means that judges may apply greater discretion. This is often applied in common law countries to make decisions in favor of minority shareholders. When one person does agree to act for another in a fiduciary relationship, the law forbids the fiduciary from acting in any manner adverse or contrary to the interests of the client, or from acting for his own benefit in relation to the subject matter. A fiduciary duty is an obligation to act in the best interest of another party.

On the other hand, in Continental Europe where the civil legal tradition exists, there are statutes and detailed legal codes; judges mechanically apply the provisions of these codes and statutes, leaving a little discretionary decision making power for the judge if there is an uncovered new issue. According to the classification of capital markets used by Mayer (1998), Moerland (1995), Franks and Mayer (2001) and Shleifer and Vishny (1997), there are essentially two types of equity markets: the outsider system and the insider system (Georgen, 1998).

The outsider system is characterized by a large number of listed firms, a dispersed ownership for the majority of these companies and control normally lying with the management. There is also an active market for the corporate control so that managerial failure can be corrected by the takeover mechanism. Common law and Anglo-Saxon countries like the U.S and the U.K are the examples of this system. According to the conventional wisdom, the outsider system puts emphasis on shareholder value, i.e. firm exists in order to maximize the shareholders' wealth.

The insider system dominates in most other countries with civil law like in Germany, France, Japan and Turkey. The insider system has a small number of quoted firms and most of them are disciplined by the large shareholder who has a concentrated power in management.

The identity of large shareholder is important in distinguishing the French civil law countries (Turkey, Italy, Netherlands, Latin countries, Belgium and Spain) and German civil law countries (Germany, Japan, East Asian countries, Austria) of the insider system. In German legal tradition countries, the banks are the controlling owners and in French legal tradition countries, especially in the emerging markets the families, individuals or business groups are the controlling shareholders.

La porta, Lopez-de-Silanes, Shleifer and Vishny (1998, pp:1127-1128) specify six anti-director rights in order to show how effectively the legal system protects minority shareholders from the expropriation of managers or controlling shareholders.

Proxy Voting: in some countries, shareholders need to show up in person on the shareholders' meeting or authorize another party to cast their votes on their behalf. In other countries, it is easier for shareholders to exercise their voting rights since they can mail their proxy vote directly to firm.

Periods of no Trading (Lock up contract): in some countries shares have to be deposited with the company or financial intermediary several days before the shareholders' meeting. The shares are held in custody up to a number of days after the meeting. This prevents shareholders from trading in the stock around price-sensitive events such as at the time of a IPO, a seasoned equity offering or any other crucial event in a firm's life cycle.

Cumulative Voting: some countries allow minority shareholders to appoint a proportional number of board members through cumulative voting. This gives more power to small shareholders to put their representatives on the board of directors.

Class Action Rights: several countries give investors the opportunity to challenge managerial decisions in court. This protects minority shareholders against oppression by management.

Preemptive Rights: in some countries, the law grants minority shareholders a preemptive right to participate in new equity issues at the same conditions as the controlling owner. The preemptive right protects investors against dilution that occurs when shares are issued to preferential investors at below market prices.

Minority Rights: La Porta, Lopez-de-Silanes, Shleifer and Vishny (1998) consider the percentage of capital needed to call an extraordinary shareholders' meeting. They assume that the higher this percentage is, the more difficult it becomes for minority shareholders to organize a meeting to question management's decisions.

LaPorta, Lopez-de-Silanes, Shleifer and Vishny (1998, p.1130) develop an anti-director index to measure the level of shareholder protection. The index number varies between 0 and 6 and higher scores imply better protection of minority shareholders' rights. The index is calculated by adding one if the country allows shareholders to mail their proxy votes; the minimum percentage of share capital that entitles a shareholder to call for an extraordinary 
shareholders' meeting is less than or equal to $10 \%$; shareholders are not required to deposit their shares prior to the shareholders' meeting; cumulative voting is allowed; an class action mechanism exists; shareholders have preemptive rights to new equity issues. As a result, they find that common law countries protect the rights of shareholders significantly better than civil law countries. On average, anti-director index equals 4 for common law countries, 3 for Scandinavian civil law countries and 2,33 for French and German civil law countries. Common law countries most frequently (39\%) allow shareholders to vote by mail, never require shareholders to deposit their shares before the meeting, most frequently $(94 \%)$ require $10 \%$ or les of capital to call for an extra-ordinary shareholders' meeting.

Djankov, La Porta, Lopez-de-Silanes and Shleifer (2006) revise the anti-director index by constructing an anti-self dealing index for 72 countries and gives numerical measures to the intensity of regulations of self-dealing. The previous paper by the same authors (1998), argue that the country's legal origin, including the common law, French civil law, German civil law, Scandinavian law, and Socialist law, is an important determinant of the country's strategy for protecting investors. In this paper, they determine the factors affecting regulations and financial development. Specifically, the index is sharply higher in common law countries than in French civil law countries. The index is also a statistically significant and economically strong predictor of a variety of measures of stock market development across countries. These results support the findings of the earlier work, but also show that theoretically-grounded measures of investor protection are closely tied to financial development.

\section{Forms of Agency Problems in Different Corporate Governance Structures and Trade-offs Between Cash Flow (Ownership) and Control (Voting) Rights}

Jensen and Meckling (1976) define an agency relation as " contract under which one or more persons (principals) engage another person (the agent) to perform some service on their behalf which involves delagating some decision making authority to the agent" (p: 308). Because there is no guarantee that the agents will act in the best interest of pricipals, agency costs are unavoidable.

In order to ensure that agent acts in the best interest of the principals, some monitoring costs are incurred by the principals and also bonding costs are incurred by the agent. Bonding activities include, for example, contractual limitations on the manager's decision-making power. Monitoring involves, for example, auditing, formal control systems, budget restrictions, and incentive compensation systems. In addition, some residual loss, which is the effective loss related to the state-contingent future of the firm and which results despite the bonding and monitoring costs incurred, is obtained. The sum of all these costs - monitoring, bonding and residual costs - is the agency cost.

Both dispersed ownership, i.e. the outsider system and concentrated ownership, i.e. the insider system give rise to agency problems. The classical principal-agent problem or conflict which causes agency costs is between a controlling manager and outside dispersed shareholders for the preceding one and is between a large controlling shareholder (or the owner-manager) and outside minority shareholders for the later one.

The instruments chosen at the corporate governance policy level to solve agency problem are different for insider and outsider systems. For example; ownership concentration, board monitoring and banks are important in insider systems. The stock market, corporate control market and equity-based compensation are important in outsider systems (Heinrich 2002, p.12).

From a corporate governance perspective, countries can be mapped into a two-dimensional space with ownership in one dimension and control rights in the other. Four main frontiers arise according to the framework of the European Corporate Governance Network: (Gugler, 2001, pp:4-7 and Becht, Roel and Bolton,1999)

- Dispersed ownership (dispersed cash flow rights) and diffused control rights (dispersed voting power : The agency problem is between management and shareholders. The advantages are liquidity and portfolio diversification (shareholders can vote or sell). The disadvantages are possibility of takeovers, free riding due to the lack of direct monitoring.

- Dispersed ownership and concentrated control rights: The agency problem is between controlling shareholders and minority shareholders. The advantage is that it encourages direct monitoring (especially when legal environment is weak and transparency is poor) and at the same time allows for liquidity and diversification. The disadvantages are potential for controlling shareholders to extract private benefits and expropriate minority shareholders through tunnelling and no active market for control can develop. Pyramid structures, multiple voting, proxy voting or shareholder agreements are examples.

- Concentrated ownership and diffused control rights: The agency problem is between the management and the shareholders. The advantage is the protection for minority shareholders by voting restrictions. The disadvantages are 
low monitoring incentives, managerial entrenchment, less liquidity, low diversification opportunities. For example; voting caps, voting on a show of hands,

- Concentrated ownership and concentrated control rights: The agency problem is between the controlling shareholders and minority shareholders. The advantages are high monitoring incentives, better alignment of cash flow and control interests. The disadvantages are low liquidity, low diversification opportunities, potential rent extraction by majority owners.

\section{Asymmetries of Ownership (Cash Flow) Rights and Control (Voting) Rights}

As a standard rule as required by international guidelines, cash flow rights should be equal to control rights so that each shareholder can exercise his power. (One share-one vote principle). In practice, in many countries, cash flow rights deviates from control rights because of provisions (capital structures or arrangements) in the company articles which give rise to the concentration or diffusion of control rights. (OECD Steering Group on Corporate Governance, 2004). Well-known OECD principles advocating one share-one vote is a determined benchmark and it is recommended that deviations from this benchmark should be disclosed to the investors.

Most commonly used asymmetries of cash flow and control around the world (or deviations from one-share-one-vote rule) are given below; (Litan, Pomerleano and Sundararajan, 2003, pp: 324-338). The practices of the same mechanisms are also explained for the Turkish companies with references to the Turkish Commercial Code and Capital Market Laws.

\section{Asymmetry Generating Mechanisms Which Concentrate Control Rights:}

- Multiple voting shares: They give the right to cast more than one vote. Sweden gives 100 times the voting power of the ordinary shares. In France, if shareholders hold their shares for at least 2 years, they can have double voting power. It protects the company from hostile takeovers. In some countries such as Austria, Germany, Belgium, UK, Italy, Norway, multiple voting share is banned. In some countries, the number of votes is limited.(Latvia and Poland). A special form of multiple voting shares is shares with preferential rights or Golden Shares. They carry more rights per share for certain matters. For example, this grants the controlling shareholder the right to elect more board members than ordinary shares. The first example of Golden Shares in Turkey is Teletaş which went public in1988. (Karsl1, 2003, p:447). According to Turkish Commercial Code, each share has one vote at minumum and companies are free to determine the voting power of one share in their company articles and in practice, multiple voting shares prevails. However, according to the Turkish Commercial Code 6762, article 387, each share has one vote in a general meeting of shareholders related to the change in the amendment of the main company article.

- Pyramids, Cross Shareholdings and Shareholder Agreements: Pyramid structures are structures of holdings and subholdings by which ownership and control are built in layers. Cross-shareholdings are reciprocal shareholdings between two companies. They both diminish the capability of non-controlling shareholders to influence corporate policy. They entrench management and make takeovers costly. They allow the family to gain a degree of control more than its share in the equity stake. Likewise, shareholder agreements enable a group of shareholders who individually may hold smaller percentages of shares to act together forming an effective majority and vote as a block. They may also contain provisions that require the parties not to sell their shares for a fixed period of time. (Lock-in agreement).

- $\quad$ Non-voting shares: They may be preffered and receive dividend and seniority in the winding up of the company but they are without the voting rights. Non-voting shares are optional in many countries. In many countries there is no limit to the use of non voting shares, but in Brasil because of its widespread use, the corporate law limited the authorized percentage of non voting shares to $50 \%$ for IPOs.

In Turkey, preferred shares are limited to the $75 \%$ of the company's capital and board members, auditors; executives are not allowed to own preferred shares. In case, there is no condition in the company article, the preferred shares automatically become common shares if the company does not pay dividends in three successive years. (Capital Market Law m.14/A, Communique no:30). Though it is allowed by law since 1992, in practice non-voting shares are not common in IPOs .

In Turkey, privileged shares usually take the form of multiple voting rights, appoinment of directors to the board, pre-determined dividend rate or seniority in the allocations of proceeds when company is liquidated. These tools have the effect of increasing the private benefits of control in favor of the majority shareholders.

- Proxy Voting: This allows shareholders to vote in absentia by delegating their voting rights to a third party, who will attend the shareholders meeting on their behalf. In some countries, the proxies should be notarized (for example, Bulgaria, Crotia and Turkey) or there are restrictions as to whom may be appointed as a proxy, such as in Egypt. Proxies can be used as an instrument to concentrate control rights in diffused ownership situations. This is 
the case in Germany, where banks may vote on behalf of shareholders whose shares are hold in custody. Proxy voting also exists in United States and Switzerland, where management makes propositions for the annual general meeting and solicits proxy votes from the shareholders.

In Turkey, in case that no contrary provision in the Articles of Association of the corporation exists, the proxy may vote for more than one shareholder. If the banks and brokerage houses exercise the voting rights as proxies on stocks which they provide custody service, the above provisions shall apply (Capital Market Board, Communique no: IV/8).

\section{Assymmetry Generating Mechanisms Which Diffuse Control Rights:}

- Minimum thresholds to initiate corporate actions: All corporate governance frameworks give minority shareholders some power. Such powers include provisions that allow minority shareholders to call a meeting, add items on the agenda, nominate board members or seek remedies. To the extent that a minority can impose its will on the majority, this represents a deviation from the "one-share-one-vote" principle. In most countries, the percentage of capital or voting rights to call a shareholders meeting is set at 5 or10 percent. However, depending on the ownership structure of the company and its free float, a 5 percent threshold might be low or high.

Under Turkish Commercial Code, the shareholders in a public company representing at least $5 \%$ of the share capital forms a minority and are entitled to certain rights under Turkish Commercial Code and Capital Market Law. They are also encouraged to reduce this minimally required percentage in their company articles. These positive minority rights are; (Yanl1, 2006)

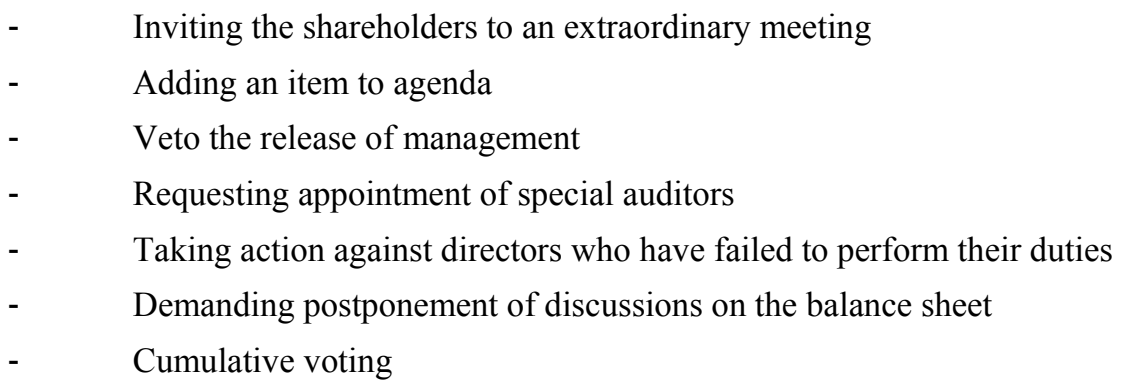

- Cumulative Voting: Cumulative voting helps minority shareholders to elect at least one director to the board even if one shareholder or a group of shareholders control an absolute majority of the voting rights. Cumulative voting may be optional or mandatory. The procedure is optional (stipulated in the articles of the company) in United States, United Kingdom, Canada, Italy and Finland. In Russia, cumulative voting is mandatory. In some countries, such as Korea, and Turkey, shareholders representing a minimum percentage of the voting rights may demand cumulative voting.

In Turkey, the shareholders in a public company representing at least $5 \%$ of the share capital form a minority and are entitled to cumulative voting. For example; a shareholder who has 30 shares may have a voting power of 90 for electing a single candidate and thus becomes more effective in electing directors of the board, because they will now have a more concentrated voting power. (Pulaşl1, 2003)

- Veto Rights (blocking minority) and Supermajority Requirements: ensure that certain corporate decisions are taken with the consent of minority shareholders. Such provisions include, for example, blocking minority or supermajority requirements for fundamental decisions and withdrawal rights.

In Turkey, these veto rights and supermajority requirements can be examplified by negative minority rights such as right not to attend to the general meetings or oppose a decision where majority of share capital is needed. (For example; a qualified majority is required to change the type of the company). Affirmative vote of minority shareholders are required for releasing the founders, board members and auditors of the company from liabilities arising from incorporation process (Ardıç, 2006).

\section{Conclusion}

This paper aims to investigate the comprehesive literature on investors protection topic and classification of different corporate governance systems of countries from various legal origins. Using this theoretical lens, more specifically, this paper analyzes different mechanisms to concentrate or diffuse control rights of companies with reference to the Turkish Commercial Code and Capital Market Laws. Accordingly, Turkey is an example of insider system country with French civil law tradition where there is a small number of stock market-listed firms most of which are disciplined by the large shareholder who has a concentrated power in management and the families, individuals or business groups are the controlling shareholders. With regard to the most commonly used 
asymmetries of cash flow and control rights around the world (or deviations from one-share-one-vote rule), the paper analyzes the relevant practices in Turkish Commercial Code and Capital Market Laws.

\section{References}

Ardıç, Pınar. (2006). "Ticaret Hukuku”, (4th ed.), Istanbul: Agon Yayıncılık.

Becht, M., Roel and Bolton, (1999). "European corporate governance: Trading off liquidity against control", European Economic Review 43, 1071-1083.

Capital Market Board of Turkey, Communique no: IV/8, $\mathrm{http}: / / \mathrm{www} . \mathrm{cmb}$. gov.tr/apps/teblig/displayteblig.aspx? $\mathrm{id}=266 \& \mathrm{ct}=\mathrm{f} \&$ action=displayfile\&ext=.pdf.

Capital Market Board of Turkey, Capital Market Law 2499, m.14/A, Communique no: 30, $\mathrm{http} / /$ www.cmb.gov.tr/apps/teblig/displayteblig.aspx? $\mathrm{id}=283 \& \mathrm{ct}=\mathrm{f} \&$ action=displayfile\&ext=.pdf.

Djankov, Rafael La Porta, Florencio Lopez-de-Silanes, Andrei Shleifer, (2006). "The Law and Economics of Self-Dealing", Paper presented at Center for company law syposium by Anton Phillips Fund, Amsterdam.

Frank and Mayer. (2001). "Ownership and Control of German Corporations", The Review of Financial Studies,14, 4, 943-977.

Goergen, Marc. (1998). "Corporate Governance and Financial Performance: A Study of German and UK Initial Public Offerings", Elgar Publishings.

Gugler, Klaus (Ed.). (2001). “ Corporate Governance and Economic Performance”, Oxford Press.

Heinrich, Ralph. (2002). "Complementaries in Corporate Governance", Springer Publications.

Jensen and Meckling. (1976). "Theory of Firm: Managerial Behavior, Agency Costs and Capital Structure”, Journal of Financial Economics, 3, 305-360.

Karsl1, M. (2004). "Sermaye Piyasası Borsa ve Menkul Kıymetler", (5th ed.). Istanbul: Alfa yayınları.

Turkish Commercial Code, Kanun metinleri dizisi. (2005). (15th ed.). Ankara: Seçkin Yayınevi.

Litan, Pomerleano, Sundararajan (Editors). (2003). "The future of Domestic Capital Markets in Developing Countries", Brookings Institution Press.

La Porta R, Lopez-de-Silanes F, Shleifer A, Vishny R.(2002). Investor protection and corporate valuation. Journal of Finance 57, 1147-1170.

La Porta R, Lopez-de-Silanes F, Shleifer A, Vishny R. (2000).” Investor protection and corporate governance.” Journal of Financial Economics 58, 3-27.

La Porta R, Lopez-de-Silanes F, Shleifer A, Vishny R. (1999). "Corporate ownership around the world.” Journal of Finance 54, 471-517.

La Porta, Lopez-de-Silanes, Shleifer and Vishny. (1999). "Corporate Ownership Around the World", Journal of Finance 54, 471-518.

La Porta R, Lopez-de-Silanes F, Shleifer A, Vishny R. (1998). "Law and Finance.” Journal of Political Economy 106, 1113-1155.

La Porta R, Lopez-de-Silanes F, Shleifer A, Vishny R. (1997). "Legal determinants of external finance". Journal of Finance 52, 1131-1150.

Mayer, C. (1998). 'Financial Systems and Corporate Governance: A Review of the International Evidence', Journal of Institutional and Theoretical Economics, Vol 154.

Moerland. (1995) "Alternative Disciplinary Mechanisms in Diffrent Corporate Systems", Journal of Economic Behavior and Organization, 26, 17-34.

OECD Steering Group on Corporate Governance. (2004) "OECD principles on Corporate Governance", OECD publications, http://www.oecd.org/dataoecd/32/18/31557724.pdf.

Poroy, Tekinalp, Çamoğlu. (2003). “Ortaklıklar ve Kooperatif Hukuku”, (9th. Ed.). Istanbul: Beta Yayınevi

Pulaşl1, Hasan. (2003). "Şirketler Hukuku”,(4th ed.). Ankara: Karahan Kitapevi.

Yanlı, V. (2006). "Sermaye Piyasası Hukuku Çerçevesinde Halka Açık Anonim Şirketler ve Kamunun Aydınlatılması",(1st.ed.). Istanbul: Beta Yayınları. 